ISSN 2078-6077.

Наукові зошити історичного факультету Львівського університету. 2020. Випуск 21. С. 305-316

Proceedings of History Faculty of Lviv University. 2020. Issue 21. P. 305-316

УДК 94:373.5.011.33](477.83-25)"184/190”(093.2)

\title{
АКАДЕМІЧНА ГІМНАЗІЯ У ЛЬВОВІ В КОНТЕКСТІ АВСТРІЙСЬКОГО ШКІЛЬНОГО ЗАКОНОДАВСТВА 1849-1909 pp.
}

\author{
Ореста КОЦЮМБАС \\ Львівський національний університет імені Івана Франка \\ кафедра новітньої історії України ім. М.Грушевського \\ вул. Університетська 1, м. Львів 79000, Україна \\ e-mail: oresta@email.ua
}

\begin{abstract}
Охарактеризовано засади функціонування Академічної гімназії у Львові відповідно до шкільного законодавства 1849 і 1909 pp. Проаналізовано освітнє законодавство, яке регулювало розвиток гімназійної освіти. Основну увагу зосереджено на змісті освіти, навчальних дисциплінах, їх статусу, забезпеченості підручниками та наочним обладнанням. Також охарактеризовано організацію навчального часу, канікулярного періоду. Звернено увагу на контроль за організацією діяльности навчального закладу з боку гімназійних інспекторів.

Ключові слова: Академічна гімназія, законодавство, навчальні плани, підручники, викладачі, гімназійні інспектори.
\end{abstract}

Історія Академічної гімназії у Львові бере початок ще в далекому 1784 р., коли на основі розпорядження австрійського імператора Йосифа II, вона почала функціонувати у структурі Львівського університету. Спочатку займала другий поверх будинку монастиря і костелу Святої Трійці, а від 1831 р. перемістилася до Бернардинського монастиря. У першій половині XIX ст. гімназія була шестикласною з латинською та частково німецькою мовами навчання. Від 1862 р. гімназія перебувала у приміщенні Народного дому (суч. вул. Театральна 22). Від вересня 1907 р. навчальний процес розпочався у новозбудованому будинку при вулиці Л. Сапєги ( сучасна вул. С. Бандери, 14), а в Народному домі функціонувала Філія гімназії. Від 1867 р. у початкових класах, а від 1874 р. в усіх класах викладання велося українською мовою ${ }^{1}$.

Зміни у структурі гімназії відбулися після “Весни народів”. Саме від 1849 р. на законодавчому рівні з’являється чітке окреслення організації гімназій як середньоосвітніх навчальних закладів.

Згідно з цісарським розпорядженням від 16 вересня 1849 р. “метою організації гімназії $є$ надання загальної середньої освіти за допомогою давніх класичних мов та літератури, а також підготова до університетського навчання"”.

\footnotetext{
${ }^{1}$ Справозданє дирекції ц. к. академічної гімназії за 1888 рік, Центральний державний історичний архів України м. Львів, ф. 178, оп.3, спр. 447, арк. 26.

2 "Rozporządzenie cesarskie z 16. września 1849, L. 6.545 dz. p.p. Nr, 393, któremi upoważniono ministerstwo oświaty do kierowania się tymczasowo przy zarządzie gimnazyów i szkół realnych zasadami zawartemi w projekcie ich organizacji”, Ustawy i rozporzadzenia obowiazujace w galicyjskich szkołach średnich zestawił Henryk Kopia, (Lwów, 1900), 1.
} 
ISSN 2078-6077. Наукові зошити історичного факультету Львівського університету. 2020. Випуск 21. Proceedings of History Faculty of Lviv University. 2020. Issue 21.

За своєю структурою гімназія складалася з чотирьох початкових класів $\mathrm{i}$ чотирьох старших. У старших 5-8 класах навчання було базовим для подальшого його продовження в університеті ${ }^{3}$.

Академічна гімназія була державною. Цей статус надавав їй право видавати свідоцтва державного зразка та проводити випускні іспити. Також, на відміну від приватних, державні гімназії ставали базовими Крайової Шкільної Ради, де проходили випробовувальні річні практики кандидати на посади гімназійних вчителів. Державні гімназії переважно фінансувалися з державного бюджету. У таких гімназіях щонайменше працювало дванадцять вчителів 3 тижневим навантаженням 12 годин ${ }^{4}$.

Відповідно до законодавства того часу, кожна національна мова могла бути мовою навчання в гімназії. Вибір мови навчання залежав від потреб і вимог місцевих жителів 5 .

У XIX ст. в гімназії викладали такі предмети: релігію, класичні мови латинську і грецьку; українську, польську і німецьку; історію і географію; природознавство, математику, фізику, пропедевтику філософії, каліграфію, малювання, співи, гімнастику.

Відповідно до законодавства 1849 р. чітко прописувалася кількість годин для кожного класу з кожної дисципліни.

Обов'язковою дисципліною в усіх восьми гімназійних класах, по дві години на тиждень в кожному, була релігія. Викладаючи релігію, учасники освітнього процесу користувалися "Катехизмом” І. Гушалевича; “Біблією - історія Старого завіту”; “Біблією - історія Нового завіту”; “Історією церкви” Д. Ільницького; “Догматикою” Ю. Пелеша'.

Латинську мову викладали у I-II класі - по 8 годин на тиждень, у III-IV - по 6 годин. У молодших класах метою вивчення предмету було граматичне знання латинської мови, майстерність і вміння перекладати легкі латинські твори. У старших класах завдання вивчати латинську мову розширювалися, зокрема вивчали латинську літературу, знайомили з римським державним устроєм та правом, 3 новими стилістичними формами латини, щоб розширювати красномовство. Латинську мову вивчали у V та VI кл. по 6 год. тижнево, а у VII та VIII кл. - по 5 тижневих годин відповідно. Під час вивчення латинської мови користувалися підручниками Е. Шульц-Огоновського "Граматика", "Вправи латинські", а також знайомились 3 латинськими творами в оригіналі.

\footnotetext{
${ }^{3}$ Stefan Ignacy Możdżeń, Ustrój szkoły średniej w Galicji i próby jego modernizacji w latach 1848-1884, (Wrocław, 1974), 17.

${ }^{4}$ Богдан Ступарик, Шкільництво Галичини (1772-1939рр.), (Івано-Франківськ, 1994), 44

5 “Rozporządzenie cesarskie z 16. września 1849, L. 6.545 dz. p.p. Nr, 393, któremi upoważniono ministerstwo oświaty do kierowania się tymczasowo przy zarządzie gimnazyów i szkół realnych zasadami zawartemi w projekcie ich organizacji”, Ustawy i rozporzadzenia, 9.

${ }^{6}$ Справозданє дирекиін й.к Гимназіи Академичнои во Львов ъ на роккь шкоิльний 1879-1880. (Львоิвь: 3 друкарн' Товариства имени Шевченка,1880), 2.
} 
Викладачі гімназії брали участь в редагуванні та рецензуванні шкільних підручників, зокрема професор гімназії К. Лучаківський у 1887 р. рецензував підручник латинської мови для гімназій

Метою вивчення грецької мови у молодших класах було граматичне вивчення форм діялогу та принципи синтаксису. Ї̈̈ викладали починаючи від III класу по 5 год; у IV кл - 4 год. на тиждень. У старших класах учні читали найвизначніші твори грецької літератури: у V, VI та VIII класах - по 5 год., у VII - 4 год. Грецьку мову вивчали за підручниками Ю. Курція “Грецька граматика для шкіл гімназіяльних", "Вправи грецькі", а також читали твори в оригіналі. Отримавши достатній лексичний запас, навики у перекладі, учні в молодших класах починали читати твори Корнелія Непота. У старших класах вивчали нотатки Юлія Цезаря про галльську війну, “Енеїду” Вергілія, твори Овідія, Лівія, Таціта, Ціцерона, Горація. 3 п'ятого класу починалася лектура грецьких авторів. Учні читали “Іліяду” і “Одісею” Гомера, твори Геродота, Демостена, Плутарха, Арістотеля, “Апологію” Платона, “Анабазис" Ксенофонта".

Українська мова була мовою навчання. У молодших класах під час викладів рідної мови основним було досягнення правильного читання та письма, без граматичних та ортографічних помилок, декламування віршів, що розвивало пам'ять. У старших класах удосконалювалася стилістична коректність, уміння грамотно писати, читати та розуміти українську класику. У навчальному плані стосовно рідної мови виділялося не менше двох годин на тиждень ${ }^{10}$.

Навчальний план вивчення української мови в середніх школах був затверджений указом Міністерством віровизнань та освіти від 12 червня 1898 р. ${ }^{11}$ У цьому плані для гімназій з переважанням учнів української національности, були передбачені такі завдання - у чотирьох нижчих класах: правильне читання і мовлення, граматична впевненість і коректність у висловленні думок усно та письмово; вивчення та декламування творів. У чотирьох вищих класах передбачалося поглиблення знань, стилістична коректність у використанні мови усно та письмово; знайомство зі складнішими творами поезії та прози; вивчення видатних творів рідної літератури і найважливіших подій у житті відомих письменників та історії літератури.

Викладаючи українську мову використували підручник викладача гімназії М. Осадци "Граматика руської мови", а також підручники: Ю. Романчука

${ }^{7}$ Рецензія на підручник латинської мови для гімназій 1887, ЦДІАУ м. Львів, ф. 178, оп. 3 , спр. 23, арк. 5.

${ }^{8}$ Справозданє дирекиі $\mathbf{t}$ и.к Гимназіи Академичнои во Львов $\mathbf{6}$ на рокь иколльний 1879-1880, 2.

${ }^{9}$ Наталія Скварок, “Класичні і новітні мови у навчальному процесі першої української львівської академічної гімназіі”, Iсторія освіти, (2010): 92, отримано доступ 18 січня 2010, http:/ /ipa.udpu.edu.ua/article/view/15249/13084

10 "Rozporządzenie cesarskie z 16. września 1849”, 21.

${ }^{11}$ Henryk Kopia, Ustawy i rozporządzenia obowiąujące w galicyjskich szkołach średnich, (Lwów, 1900), 22. 
ISSN 2078-6077. Наукові зошити історичного факультету Львівського університету. 2020. Випуск 21. Proceedings of History Faculty of Lviv University. 2020. Issue 21.

“Читанка для низших середніх шкіл” у двох частинах, видана під керівництвом директора гімназії В Ільницького ${ }^{12}$; "Руською читанкою для нижчих клас середніх шкіл” О. Партицького ${ }^{13}$; "Рускою читанкою для высшои гимназии" О. Барвінського; “Хрестоматією руської літератури" Я. Головацького. За задумом Я. Головацького, хрестоматія була розрахована не лише для вжитку у школах, але й для частини освічених та патріотично налаштованих галицьких русинів ${ }^{14}$.

Для вивчення польської та німецької мов служили "Граматика польська" А Малецького; для німецької мови "Граматика німецька" Я. Калужняцького, а також "Вправи німецькі і читання німецьке"15.

Вивчаючи географію, учнів знайомили з формою та розміром Землі, рухом Сонця та пояснювали зміни в освітленні та нагріванні земної поверхні. Учнів навчали орієнтуватися на картах та в атласах.

3 історії вивчали біографії видатних людей, а також основні події в історії Австро-Угорської монархії. Акцентували увагу на вивченні щорічних визначних дат. Звертали увагу учнів, що цінним джерелом інформації $є$ науковий матеріял у вигляді свідчень. У I та III класах на цей предмет виділяли по три години щотижнево, а у II та IV - по 4 год. на тиждень. Від учнів старших класів уже вимагали знання найважливіших подій історії народів світу, їх відносини та залежність від природніх умов, а також історичний розвиток греків, римлян та Австро-Угорської монархії ${ }^{16}$. Кількість годин, виділених на вивчення цієї дисципліни, була такою: у V, VII та VIII класах - по 3 год; у VI - 4 год. на тиждень. Географію викладали на базі підручника А. Вахнянина "Учебник географії для шкіл середніх". Для вивчення природничих дисциплін використовували підручники "Ботаніка" І. Верхратського; "Мінералогія" М. Полянського ${ }^{17}$. Перекладені були "Ботаніка" і “Зоологія” К. Шедлера ${ }^{18}$.

У старших класах гімназії учні отримували грунтовні математичні знання та вміли ними оперувати на практиці. Дисципліну ділили на дві частини - аритметику

12 Володимир Булачек, “Просвітня діяльність Юліана Романчука”, Украӥна: культурна спадщина, національна свідомість, державність, No. 19 (2010):381, отримано доступ 27 січня 2019, http://www.inst-ukr.lviv.ua/files/21/020Bulachek.pdf. 20.

${ }^{13}$ Справозданє дирекці ъ и.к Гимназіи Академичнои во Львовъ на роккь шкоิльний 1879-1880,

${ }^{14}$ Олександр Седляр, “Хрестоматія руської літератури Якова Головацького як інформаційний та освітній проект: плани та їх реалізація”, Вісник Львівського університету. Серія книгознавство, бібліотекознавство та інформаційні технологіï, №. 7(2012):25.

${ }^{15}$ Справозданє дирекиін й.к Гимназіи Академичнои во Львов ъ на роккь школьний 1879-1880, 20.

16 "Rozporządzenie cesarskie z 16. września 1849”, 26.

${ }^{17}$ Петро Білоніжка, “Перші підручники з мінералогії, видані українською мовою у другій половині XIX ст.”, Мінералогічний збірник, №. 54.1 (2004):172-181, отримано доступ 11 лютого 2019, http://old.geology.lnu.edu.ua/Science/science_reports/zvit_2004.pdf.

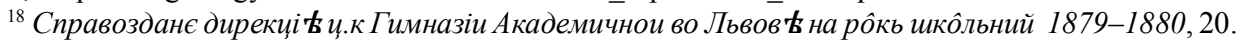


та геометрію в усіх класах. Щодо тижневого навантаження, то воно складало 3 години на тиждень ${ }^{19}$. Для математики базовими підручниками слугували, “Аритметика", яку в 1873 р. переклали О. Дейницький та Т. Іскрицький та “Аритметика й алгебра для вищих класів середніх шкіл”, яку переклав з німецької в 1877 р. Є. Савицький ${ }^{20}$.

Викладачі природознавства у молодших класах знайомили учнів 3 найважливішими різновидами органічного та неорганічного світу, застосовувавши при цьому безпосередній перегляд експонатів. У старших гімназійних класах це був систематичний огляд груп тварин і рослин на основі відомостей з їх морфології, анатомії та фізіології, знання форм і властивостей найважливіших мінералів разом 3 ознайомленням про будову і розвиток земної кулі. Природознавство, за навчальним планом 1849 р., викладали у трьох молодших та трьох старших класах по 2 год. щотижня. Також у процесі вивчення цей предмет поділяли на зоологію і ботаніку.

Вивчаючи фізику, учні опановували знання про природу, походження найпоширеніших природних явищ на основі спостереження та експерименту. За програмою фізику викладали у III класі по 2 год. та у IV кл. -3 год. в тиждень. Учні вивчали властивості магнетного поля, а також такі розділи фізики, як електрика та механіка, властивості світла та ін. У старших VII та VIII класах вивчали такі розділи, як механіка, магнетизм, електрика та електричний струм, рух хвиль, акустику, оптику та астрономію.

Завданням вивчення філософії було доповнити емпіричну інформацію про зовнішній світ за допомогою досвіду на основі розуміння духового життя, а також вивчити найзагальніші форми мислення. Пропедевтика філософії ділилась на логіку та емпіричну психологію, викладали іï по 2 год. на тиждень у VII та VIII кл. ${ }^{21}$ Цей предмет викладали на основі підручників “Логіка" та "Психологія" в перекладі В. Ільницького 22 .

Необов'язкові дисципліни - каліграфія, малювання, співи, гімнастика, відвідували учні відповідно до бажань та зацікавлень. Навчальні плани 3 цих дисциплін розробляли викладачі і подавали затверджувати до шкільної ради. Поступово був розроблений і затверджений план науки малювання для гімназій та реальних шкіл від 17 червня 1891 р. ${ }^{23}$ Також 2 лютого 1897 р. затверджено навчальний план гімнастики, як обов' язкової дисципліни для кожного гімназійного класу по дві година на тиждень під керівництвом фахового викладача.

Навчання історії рідного краю також регулював навчальний план за розпорядженням Крайової шкільної ради від 1 жовтня 1873 року. Викладання історії рідного краю викладали в III та IV класі. Для старших VII та VIII класу

19 “Rozporządzenie cesarskie z 16. września 1849”, 29.

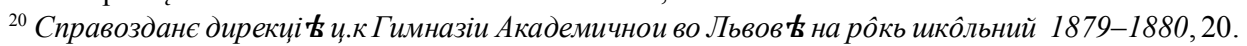

21 "Rozporządzenie cesarskie z 16. września 1849", 34.

${ }^{22}$ Справозданє дирекиін й.к Гимназіи Академичнои во Львов '九 на роิкь шкоิльний 1879-1880, 21.

23 "Rozporządzenie cesarskie z 16. września 1849", 35. 
ISSN 2078-6077. Наукові зошити історичного факультету Львівського університету. 2020. Випуск 21. Proceedings of History Faculty of Lviv University. 2020. Issue 21.

навчальний план історії рідного краю вступив в дію за розпорядженням Крайової шкільної ради від 2 березня 1891 p. $^{24}$

Розпорядженням від 2 серпня 1909 р. Крайова шкільна рада видала новий план навчання в галицьких гімназіях, затверджений Міністерством віросповідань та освіти рескриптом від 6 липня $1909 \mathrm{p}^{25}$

Реформа 1909 р., була прогресивною, оскільки раціоналізувала зміст середньої освіти, зокрема дисципліни природничо-математичного циклу, матеріял яких приведено у відповідність 3 рівнем розвитку університетської науки. До обов'язкових навчальних предметів належали: релігія - 2 год. на тиждень в усіх класах; українська мова (як мова викладання) по 3-4 год. на тиждень; латинська мова - 5-6 год. на тиждень; грецька мова починаючи від III кл. - 4-5 год. на тиждень; німецька мова - 4-5 год. на тиждень; історія 2-3 год. на тиждень; географія по 2 год. на тиждень у молодших класах; математика 3 год. на тиждень; історія природи по 2 год. у двох молодших і двох старших класах; фізика і хімія - 2-4 год. на тиждень у двох молодших і двох старших класах; пропедевтика філософії в VII кл. - 1 год., а у VIII кл. - 2 год.; польська мова 2 год. на тиждень в усіх класах ${ }^{26}$. Каліграфія стала обов'язковим предметом для I гімназійного класу в кількості 1 год. на тиждень ${ }^{27}$.

Серед нововведень плану були: введення обов'язкового вивчення німецької мови; введення другої національної мови, як факультативної або обов'язкового предмету навчання; збільшенням кількости тижнів навчання; введення загальної історії як обов 'язкової дисципліни. Навчальний план 1909 р. запроваджено в дію від початку 1909-1910 навчального року. У його впровадженні шкільні адміністрації та викладачі зіткнулися з низкою проблем, пов' язаних з відсутністю підручників та зміною змісту дисциплін і методики викладання.

Кількість тижневого навантаження в гімназії в середньому складала 25 годин, навчання проходило шість днів на тиждень. Навчання відбувалося до обіду, а три дні ще й у післяобідній час. Теоретичне навчання проходило в дообідні навчальні години, після обіду, зазвичай, проводили заняття з гімнастики. Необов'язкові дисципліни в тижневому годинному навантаженні не могли перевищувати кількість обов'язкових дисциплін. Перед третьою та четвертою

\footnotetext{
24 “Okólnik do Dyrekcyi c.k.gimnazyów wyznaczając nauke historyi krajowej 22 marca 1891 L.5906", Sprawozdanie c. k. Rady szkolnej krajowej o stanie szkót średnich galicyjskich w roku szkolnym 1890/91, (Lwów, 1891), 21, отримано доступ 14 грудня 2018, https://www.pbc.rzeszow.p1/ dlibra/publication/5954/edition/5474.

25 "Stan nauki”, Sprawozdanie c.k. rady szkolnej krajowej o stanie Galicyjskich szkot średnich w roku szkolnym 1908-1909, (Lwów, 1909), 83, отримано доступ 15 грудня 2018, https://www.pbc.rzeszow.pl/ dlibra/publication/6099/edition/5513.

26 "Plan nauki dla gimnazjów galicyjskich. Rozporządzenie c.k. Rady Szkolnej Krajowej z dnia 2 sierpnia 1909 L.44.242”, (Lwów, 1909), 14, отримано доступ 11 лютого 2017, https:// www.pbc.rzeszow.pl/dlibra /publication/5175/edition/4775.

27 Звіт дирекиї̈ ич.к. академічної гімназї̈ у Львові за рік шкільний 1909-1910. (Львів: 3 друкарні наукового товариства імени Шевченка, 1910), 86.
} 
годиною навчання, були десятихвилинні перерви, під час яких учні виходили в коридор чи на подвір'я, клас провітрювали.

Від 1893-94 навчального року навчання в гімназії проходило від 8 ранку до 13 години дня, а заняття з необов'язкових дисципліни проводили тричі на тиждень після обіду. Також додали перерви перед четвертою годиною навчання 1520 хвилин, перед п'ятою 10-15 хвилин ${ }^{28}$.

Для ознайомчого та практичного супроводу навчального процесу, для учнів та викладачів щороку поповнювали вже існуючі шкільні бібліотеки та гімназійні кабінети. Станом на 1889 рік викладацька бібліотека налічувала 4419 книжок та 2984 журнали, учнівська бібліотека налічувала 2721 книжку. Кабінет фізики був обладнаний 307 приладами, в хемічній лабораторії їх було 45. Кабінет природознавства зберігав 961 біологічний екземпляр та 1440 ботанічні експонати; мінералогічна колекція кабінету містила 620 мінералів, 193 кристалографічні моделі, 100 окаменілостей органічного походження, шкалу твердости, 18 скляних моделей дорогоцінного каміння та 10 скляних форм шліфованих дорогоцінних каменів. Для практичного вивчення географії та історії в гімназії було 95 настінних карт, 31 атлас та три глобуси ${ }^{29}$. Наявність матеріялів та експонатів, котрі використовували в навчальному процесі, щороку поповнювали за рахунок державних коштів, а також завдяки меценатам.

Викладачі гімназії багато уваги і часу приділяли написанню підручників. Особлива увага зверталася на підготову оригінальних українських підручників. У 1868 р. при Крайовій Шкільній Раді у Львові утворено польську та українську спеціяльні комісії, котрі займалися написанням шкільних підручників. Викладач гімназії Юліян Романчук, як учасник української комісії, у 1869 р. писав, що одним 3 перших завдань комісії було укласти українську термінологію для граматики, а згодом і до інших дисциплін. Від 1886 р. функцію виготовлення шкільних підручників продовжила “Наукова Комісія" з семи членів при Крайовій Шкільній Раді ${ }^{30}$.

Міністерство віровизнань і освіти ретельно слідкувало та законодавчо регламентувало процес забезпечення гімназійної освіти шкільними підручниками. Зокрема, при наявності затвердженого та апробованого підручника, вчителі обов'язково мали ним користуватися. Шкільні підручники мали бути чітко структуровані, містити детальний план та бути доступними учням. Викладаючи, вчитель повинен орієнтуватися на підручник, але все ж мав читати учням лекцію, а підручником учні користувалися вдома, щоб закріпити матеріял. За зверненням вчителів шкільний підручник можна було замінити на якісніший. Запроваджували в навчальний процес підручник чи іншу методичну розробку на прохання

28 "Rozporządzenie cesarskie z 16. września 1849", 37.

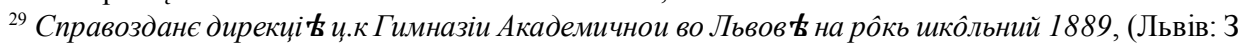
друкарн中 Товариства имени Шевченка, 1889), 19.

${ }^{30}$ Юліян Романчук, “Українська Комісія для виготовлення шкільних підручників" Двадиятип'ятиліття товариства “Учительська громада”, (Львів, 1935), 133. 
ISSN 2078-6077. Наукові зошити історичного факультету Львівського університету. 2020. Випуск 21. Proceedings of History Faculty of Lviv University. 2020. Issue 21.

педагогічного колективу. Крайовий шкільний інспектор стежив за тим, чи використовують у навчанні апробовані підручники, а також за тим, щоб підручники були в учнів. ${ }^{31}$

Наприкінці століття проблема забезпечення гімназій підручниками входила до сфери повноважень крайового інспектора середніх шкіл. Крайовий інспектор Іван Копач зініціював перенести склад українських гімназійних підручників 3 приватної книгарні до книгарні Наукового товариства ім. Шевченка у Львові ${ }^{32}$. Коли видання шкільних підручників було компетенцією Крайової шкільної ради, то вона щорічно отримувала на це субвенцію від Галицького сойму в розмірі 8000 корон $^{33}$.

Оскільки перші україномовні підручники для Академічної гімназії були перекладені з німецької, складні термінологічно і мали невеликий наклад, то їх видавали товариства "Галицько-руська матиця" та "Ставропігія", згодом товариство "Просвіта". Гімназійні викладачі Ю. Романчук та К. Лучаківський в 1871 р. упорядкували “Читанку для 1-ої і 2-ої кляси середніх шкіл”, котру видало товариство "Просвіта".

Окрім питання забезпечености гімназії підручниками, крайовий інспектор відповідав за проведення випускних іспитів, реагував на конфліктні ситуації між учнями та викладачами. Від 1850 р. гімназійним інспектором був Євсевій Черкавський, який був прихильником відходу від "російщини”, та для української справи вважав доцільнішим впровадити в навчання “польську абетку", пристосовану до української мови ${ }^{34}$.

Наступним гімназійним інспектором став Іван Левицький ${ }^{35}$. Як згадує тодішній учень гімназії Степан Шах, він був “типовим австрійським вищим урядовцем, для якого цісар був ідолом, якого всі язики в монархії мали хвалити, а всі руки “спільними силами” мали для монарха працювати, бо був він справедливим, шанував однаково всі нації, а католицизм був його святістю"зб. За фахом був істориком, але за спогадами гімназистів був дуже прискіпливий до учнів під час випускних екзаменів, особливо з математики і фізики"з7.

\footnotetext{
31 "Podręczniki szkolne", Ustawy i rozporzadzenia obowiqzujące w galicyjskich szkołach średnich zestawil Henryk Kopia, (Lwów, 1900), 40.

${ }^{32}$ Степан Сірополко, Історія освіти в Украӥні, (Київ: Наукова думка, 2001), 212.

${ }^{33}$ Іван Копач, “3 історії українських шкільних книжок”, Двадиятип'ятиліття товариства “Учительська Громада”, (Львів, 1935), 137.

${ }^{34}$ Степан Шах, Львів - місто моєї молодости. Цісарсько-Королівська Академічна Гімназія, (Львів: Видавництво НУ “Львівська політехніка”, 2010), 27.

${ }^{35}$ Sprawozdanie c. k. Rady szkolnej krajowej o stanie szkót średnich galicyjskich w roku szkolnym 1906-1907,(Lwów, 1904), 3, отримано доступ 10 грудня 2018, https://www.pbc.rzeszow.pl/dlibra/ publication/6063/edition/5492.

${ }^{36}$ Степан Шах, Львів - місто моєї молодости, 28.

${ }^{37}$ Михайло Дуркот, “3 юних днів, днів весни”. (Мої шкільні спомини заперед 40 літ”, Звідомлення виділу Кружка родичів при Державній гімназї̈ з українською мовою навчання в Перемишлі за шкільний рік 1935-36, (Перемишль, 1976), 107.
} 
Від 1908 р. Крайова шкільна рада призначила гімназійним інспектором професора гімназії Івана Копача, який зарекомендував себе як здібний український публіцист, педагог та громадсько-політичний діяч. Разом з Антоном Крушельницьким він уклав нову українську читанку, а з Прокопом Мостовичем упорядкував підручник з латинської мови. Був дійсним членом Наукового товариства імени Шевченка, очолював товариства “Боян” і “ Українська Бесіда" ${ }^{38}$.

У навчальному процесі шкільне законодавство окремо виділяло канікулярні періоди та вихідні дні. Навчальний рік ділився на два півріччя: від 2 вересня до 30 січня перший семестр. Другий семестр починався від 3-го лютого і тривав до 15 липня. Гімназисти звільнялися від навчання, окрім недільних ще і у релігійні святкові дні. Вихідними були: 4 жовтня - день іменин імператора Франца Йосифа, та 19 листопада - день св. Слизавети; вихідними були і дні Різдвяних свят, зокрема від 23 до 28 грудня. Під час Великодніх свят вихідними були з середи перед Великоднем, до середи після. Літні канікули тривали від 15 липня до 1 вересня. У три перші вересневі дні, коли проводилися вступні іспити та перездачі за попередній рік, а також святкові богослужіння, навчання не було ${ }^{39}$.

На початку XX ст. в гімназії працювало 25 викладачів, більшість 3 яких мали звання гімназійного професора, навчалося понад тисячу учнів. У період 18751914 рр. гімназію закінчили 2122 учні, більшість 3 яких продовжили навчання в університеті. Серед учнів гімназії упродовж 1875-1914 pp. 99\% були українцями, і лише приблизно 1\% - поляками. Академічна гімназія у Львові була забезпечена сучасним приміщенням, бібліотекою, просторою спортивною залою, обладнаними кабінетами фізики і хімії, природознавства, географії та історії. Учні мали достатню кількість підручників. Навчальний і виховний процес в гімназії перебував під пильним контролем гімназійних інспекторів.

Отже, Академічна гімназія у Львові, як перша українська середньо освітня державна установа, цілком відповідала змісту, який декларувало освітнє законодавство. I до початку XX ст. гімназія перетворилася на потужний український навчальний заклад, який вніс вагомий вклад в підготову національної еліти Східної Галичини.

\footnotetext{
${ }^{38}$ Євген Нахлік, “В інтелектуальній орбіті Івана Франка : Іван Копач”, Українське літературознавство, No.74, (2011), 166.

39 "Co nabożeństw kończączych i zaczynających rok szkolny, rozp. m. w. i o. z 15. grud. 1854, 1. 18.748” , Ustawy i rozporzadzenia obowiazujace w galicyjskich szkołach średnich zestawit Henryk Kopia, (Lwów, 1900), 38.
} 
ISSN 2078-6077. Наукові зошити історичного факультету Львівського університету. 2020. Випуск 21.

Proceedings of History Faculty of Lviv University. 2020. Issue 21.

\title{
THE ACADEMIC GYMNASIUM IN LVIV IN THE CONTEXT OF THE AUSTRIAN SCHOOL LEGISLATION 1849-1909 years
}

\author{
Oresta KOTSIUMBAS \\ Ivan Franko National University of Lviv, \\ Department of Modern History of Ukraine named after. M. Hrushevsky, \\ University St. 1, Lviv, 79000, Ukraine \\ e-mail: oresta@email.ua
}

The Academic Gymnasium in Lviv was founded in 1784 on the basis of Emperor Joseph's II order and functioned as one of the Lviv University's brunches. The gymnasium was a six-year high school with Latin and partly German languages of education. Since 1867 in elementary school, and since 1874 in all classes the teaching was conducted in Ukrainian. Starting with the reform of the high school in 1849 and basing on the "Organizational Essay on High Schools and Actual Schools in Austria" and the "Normative Plan of Science for Gymnasia", one can trace the clarity of the state educational regulation of an educational institution.

The curricula were adopted and implemented at the legislative level, which had a clearly defined content of the disciplines and the number of hours allocated for their study. The curricula were also dedicated to the study of classical languages - Latin and Greek. In addition, they taught religion, Ukrainian, German, Polish; history, geography, natural science; mathematics, physics, and philosophy. Painting and singing were considered as optional subjects. At the end of the century gymnastics became a compulsory discipline.

In 1909, in Austro-Hungarian grammar schools, including the Academic Gymnasium of Lviv, new curricula were introduced. It improved the content of secondary education and increased the number of hours to study the natural-mathematical cycle of disciplines in accordance with the level of development of university education. Among the innovations of the plan were the following: the compulsory study of the German language; the second national language as an optional or compulsory subject; an increasing in the number of weeks of study and introduction of general history as a compulsory discipline. The curriculum of 1909 year was enacted with the beginning of 1909-10 academic year. In its implementation, school administrations and teachers faced a number of problems related to the absence of textbooks and changes in the content of disciplines and teaching methodology. It should be noted that the publication of textbooks belonged to the competence of the Regional School Council.

Accordingly, the control over the organization of the educational institution, the availability of educational and methodological literature, control over the moral - professional level of teachers as well as organization and conducting of the gymnasium examinations belonged to the competence of gymnasium inspectors.

The issues of organization of educational space and teaching process were completely regulated. The Academic Gymnasium in Lviv owned modern facilities including library, spacious sports hall, equipped with cabinets of physics and chemistry, natural science, geography and history. Students had enough textbooks. The educational and upbringing processes in the gymnasium were under the strict control of gymnasium inspectors. At the beginning of the 20 th century, 25 teachers worked in the gymnasium, most of whom had the title of a gymnasium professor, and taught more than a thousand students. During the period of 1875-1914, 2122 students graduated from the gymnasium, most of whom continued their studies at the university. Among the students of the gymnasium during 18751914. $99 \%$ were Ukrainians, and only about $1 \%$ were Poles.

To sum up, the Academic Gymnasium in Lviv, as the first Ukrainian secondary educational state institution, fully corresponded to the content that was declared by the educational law. And by the beginning of the XXth century, the gymnasium turned into a powerful Ukrainian educational institution, which made a significant contribution to the upbringing of the national elite of the Eastern Galicia.

Key words:Academic Gymnasium, legislation, curriculum, textbook, teacher, gymnasium inspector. 


\section{REFERENCES}

Bulachek, Volodymyr. "Prosvitnia diialnist Yuliana Romanchuka", Ukraina: kulturna spadshchyna, natsionalna svidomist, derzhavnist, No. 19 (2010): 381, accessed Sichen 27,2019, http://www.inst-ukr.lviv.ua/files/21/020Bulachek.pdf.(in Ukrainian).

Bilonizhka, Petro. "Pershi pidruchnyky z mineralohii, vydani ukrainskoyu movoyu u druhii polovyni XX st.”, Mineralohichnyi zbirnyk, No. 54.1 (2004): 172-181, accessed Liutyi 11, 2019, http://old.geology.lnu.edu.ua/Science/science_reports/zvit_2004.pdf. (in Ukrainian).

Durkot, Mykhailo "Z yunykh dniv, dniv vesny". (Moyi shkilni spomyny zapered 40 lit”, Zvidomlennia vydilu Kruzhka rodychiv pry Derzhavnii himnazii z ukrainskoiu movoiu navchannia v Peremyshli za shkilnyi rik 1935-36, (Peremyshl, 1976), 240. (in Ukrainian).

Zvit dyrektsii ts.k. akademichnoi himnazii u Lvovi za rik shkilnyi 1909-1910. (Lviv: Z drukarni naukovoho tovarystva imeny Shevchenka, 1910), 86. (in Ukrainian).

Kopach, Ivan. "Z istorii ukrainskykh shkilnykh knyzhok", Dvadtsiatypiatylittia tovarystva "Uchytelska Hromada", (Lviv, 1935), 137. (in Ukrainian).

Kopia, Henryk. Ustawy i rozporzadzenia obowiazujące $w$ galicyjskich szkołach średnich, (Lwów, 1900), poz. 187. (in Polish)

Możdżeń, Stefan Ignacy. Ustrój szkoły średniej w Galicji i próby jego modernizacji w latach 1848-1884, (Wrocław, 1974), poz. 150. (in Polish)

Nakhlik, Yevhen. "V intelektualnii orbiti Ivana Franka : Ivan Kopach", Ukrainske literaturoznavstvo, No.74, (2011), 164-173. (in Ukrainian).

Okólnik do Dyrekcyi c.k.gimnazyów wyznaczając nauke historyi krajowej 22 marca 1891 L.5906"' Sprawozdanie c. k. Rady szkolnej krajowej o stanie szkół średnich galicyjskich w roku szkolnym 1890-91, (Lwów, 1891), 21, accessed Hruden 27, 2019, https:// www.pbc.rzeszow.p1/dlibra/publication/5954/edition/5474. (in Polish)

"Plan nauki dla gimnazjów galicyjskich. Rozporządzenie c.k. Rady Szkolnej Krajowej z dnia 2. sierpnia 1909 L.44.242”, (Lwów, 1909), accessed Liutyi 11, 2017, https://www.pbc.rzeszow.pl/ dlibra/publication/5175/edition/4775, poz. 38. (in Polish)

"Podręczniki szkolne", Ustawy $i$ rozporzadzenia obowiazujace $w$ galicyjskich szkołach średnich zestawit Henryk Kopia, (Lwów, 1900), poz. 187. (in Polish)

Retsenziia na pidruchnyk latynskoi movy dlia himnazii 1887, Centralnyi derzhavnyi istorychnyi arkhiv Ukrainy m. Lviv, f. 178, op. 3, spr. 23, 17ark. (in Polish)

Romanchuk, Yulian. "Ukrainska Komisiia dlia vyhotovlennia shkilnykh pidruchnykiv" Dvadtsiatypiatylittia tovarystva "Uchytelska hromada", (Lviv, 1935),133-136. (in Ukrainian).

"Rozporządzenie cesarskie z 16. września 1849, L. 6.545 dz. p.p. Nr, 393, któremi upoważniono ministerstwo oświaty do kierowania się tymczasowo przy zarządzie gimnazyów i szkół realnych zasadami zawartemi w projekcie ich organizacji”, Ustawy i rozporzadzenia obowiąujące w galicyjskich szkołach średnich zestawił Henryk Kopia, (Lwów, 1900), poz. 187. (in Polish)

Sedliar, Oleksandr. "Khrestomatiia ruskoi literatury Yakova Holovatskoho yak informatsiinyi ta osvitnii proekt: plany ta yikh realizatsiia", Visnyk Lvivskoho universytetu. Seriya knyhoznavstvo, bibliotekoznavstvo ta informatsiini tekhnolohii, No. 7 (2012): 25. (in Ukrainian).

Siropolko, Stepan. Istoriia osvity v Ukraini, (Kyiv: Naukova dumka, 2001), 551. (in Ukrainian).

Skvarok, Nataliia. "Klasychni i novitni movy u navchalnomu protsesi pershoi ukrainskoi lvivskoi akademichnoi himnazii”, Istoriya osvity, (2010): 92, accessed Sichnia 18, 2010, http://ipa.udpu.edu.ua/article/view/15249/13084 (in Ukrainian). 
ISSN 2078-6077. Наукові зошити історичного факультету Львівського університету. 2020. Випуск 21.

Proceedings of History Faculty of Lviv University. 2020. Issue 21.

Spravozdanie dyrektsii ts. k. akademichnoi himnazii za 1888 r., Centralnyj derzhavnyi istorychnyi arkhiv Ukrainy m. Lviv, f. 178, op.3, spr. 447, 86 ark. (in Ukrainian).

Spravozdanie dyrekcii c.k. gymnazia àkademichnoy vo Lvovi na rok shkolnyi 1879-1880. (Lvov: Z drukarni Tovarystva imeny Shevchenka,1880), 33. (in Ukrainian).

Spravozdanie dyrektsiyi ts.k. gymnazii akademychnoy vo Lvovi za rok shkolnyi 1889, (Lviv: Z drukarni Tovarystva imeny Shevchenka, 1889), 44. (in Ukrainian).

Sprawozdanie c. k. Rady szkolnej krajowej o stanie szkót średnich galicyjskich wroku szkolnym 1906-1907, (Lwów, 1904), accessed Hruden 10, 2018, https://www.pbc.rzeszow.pl/dlibra/ publication/6063/edition/5492. poz. 84. (in Polish)

"Stan nauki", Sprawozdanie c.k. rady szkolnej krajowej o stanie Galicyjskich szkot średnich w roku szkolnym 1908-1909, (Lwów, 1909), 83, accessed Hruden 15, 2018, https:// www.pbc.rzeszow.pl/dlibra/publication/6099/edition/5513. (in Polish)

Stuparyk, Bohdan. Shkilnytstvo Halychyny (1772-1939 rr.), (Ivano-Frankivsk, 1994), 143. (in Ukrainian).

Shakh, Stepan. Lviv - misto moyei molodosty. Tsisarsko-Korolivska Akademichna Himnaziia, (Lviv: Vydavnytstvo NU “Lvivska politekhnika”, 2010), 240 . (in Ukrainian).

“Co nabożeństw kończączych i zaczynających rok szkolny, rozp. m. w. i o. z 15. grud. 1854, 1. 18.748”, Ustawy i rozporządzenia obowiazujace w galicyjskich szkołach średnich zestawit Henryk Kopia, (Lwów, 1900), poz. 187. (in Polish) 